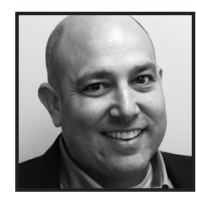

\title{
Developing an Inquiring Community of Practice: Case Stories From One Middle School's Efforts for Partnership
}

Frank LaBanca, National Center for Inquiry Learning

\section{ABSTRACT}

At a start-up urban magnet middle school, we are committed to a student-centered inquiry-based learning environment that values extended project-based learning. In order to make projects relevant, we work with community members to harness their expertise in the design, execution, and evaluation of student work. We recognize that partnerships that allow community members to showcase their own talents, skills, and knowledge forge meaningful relationships that enhance student learning.

\section{Context for Leadership and Learning}

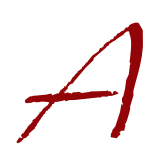

$s$ the Founding Principal of a start-up urban magnet middle school housing two theme-based academies, I was excited to bring my many years of practice and research to develop a meaningful, robust vision of learning. While the school boasted both a STEM (Science, Technology, Engineering, and Mathematics) and a Global Studies academy, I was determined to bring a unified vision of student-centered, technology-enhanced, inquiry-based instruction where students conducted extended, authentic projects that had value to communities beyond the four walls of each classroom.

As a public urban magnet middle school, we serve grades six to eight. We have a diverse population of students: approximately $40 \%$ of our students receive free 
or reduced lunch, and $51 \%$ of our student population is from underrepresented groups, the largest being Latino (31\%). In addition to core academic classes, we offer students a choice of Spanish or Mandarin Chinese and have some unique offerings for special area classes that complement our themes: digital media, broadcast journalism, and engineering.

At the core of the educational philosophy of the school was a field-tested, learning theory-based, evidence-rooted instructional model that demonstrated increased student achievement, especially for underserved students (LaBanca et al., 2014). I had previously led the development, implementation, and evaluation of this nationally funded model. This Blended Instruction learning model (LaBanca, Worwood, LaSala, Schauss, \& Donn, 2013) applies concepts of blended learning, experiential learning, digital portfolios, and proficiency-based challenge projects, all centered through ongoing teacher training.

In order to maintain model fidelity, we provide summer-institute training complemented with regular professional development meetings and in-class coaching for all teachers (LaBanca, Lorentson, \& Oh, 2016). We also schedule opportunities for team planning with an instructional coach to further advance our educational goals.

We constantly recognize that our practice must be rooted in learning theory and evidence and therefore have centered our mission on that philosophy (see Figure 1). Ultimately, we want students to develop relevant projects specific to their academy theme that harness students' creative problem finding and logical/analytical problemsolving skills. Since relevance is so important to us, we fully recognize that this process necessitates partnership with our community. Operating now for two years, we begin our third year positioned to enhance and continue developing the partnerships that extend the expertise of the faculty. 


\section{W/ESTSIDE \\ ACADEMY}

VISION

Our vision is to create a 6th-8th grade inquiry-oriented middle school that is highly regarded for its academic excellence and rigorous curriculum, where students are inquisitive, community-serving, self-directed learners.

\section{MISSION}

Inspired by the need to meet the demands of an ever-changing global society, Westside Middle School Academy empowers all students to be inquiring learners, creative problem solvers, and responsible citizens through our rigorous curricula, safe learning environment, and wide variety of educational opportunities.

Fig 1. Westside Middle School Academy vision and mission

\section{Practice Rooted in Theory and Evidence}

\section{Experiential Learning}

As part of the school's instructional model, experiential learning is key to the success of successful project-based learning. Experiential learning is learning that engages students in applying knowledge and conceptual understanding to authentic problems or situations (Wurdinger \& Carlson, 2010). In this model, the educator directs and facilitates learning. Key to knowledge and skill acquisition for the students is reflection on learning (Felicia, 2011). Based on the work of Kolb (1984), the key learning facets of experiential learning are (a) active involvement in the experience; (b) reflection on the experience; (c) an understanding of the analytical skills to necessary to conceptualize the experience; and (d) decision-making and problem-solving skills to apply concepts learned from the experience.

Experiential learning manifests as forged partnerships between students and adult experts. In our context, these adult experts are most often not the faculty members of the school. These professionals are community members with expertise specific to the themes of the Academies: our students partner with practicing scientists and engineers in STEM and with historians and community leaders in Global Studies. This work and learning occurs via these mentors coming to the school as well as through students visiting work sites. Through these experiential apprenticeships students gain an understanding of the process, content, and context of real world. 
Learning theory rooted in situated cognition. Brown, Collins, and Duguid (1989) suggested that activities in context are integral to learning. The main tenet of situated cognition learning theory is that learning knowledge and skills occur best when they are in a context that reflects the way they will be used in real life (Collins, 1988) and that knowledge is conceived as lived practice (Driscoll, 2005). In essence, the sociocultural setting and activities of individuals drive the acquisition of knowledge. Learning for students occurs as they participate in a community of practice. Students learn from experts, and, in turn, the experts learn from students. Learning becomes a collaborative process in which all participants learn through their actions (Driscoll, 2005).

The goal is to help students move from neophytes to more capable and independent researchers, who learn to use their expertise, intuition, and deep understanding of content to solve problems of their choosing. A nonlinear, idiosyncratic process occurs students learn (see Figure 2). Genuine experiences help the individual learn advanced abstract concepts. The experiences can result in learning pathways, which allow students to accumulate information to learn and become a member of the community of practice. Throughout the process, critical thinking and reflection lead to the refinement of ideas and the consideration of alternate possibilities. In a situated cognition setting, learners are empowered to traverse pathways that garner new knowledge (Orey, 2010).

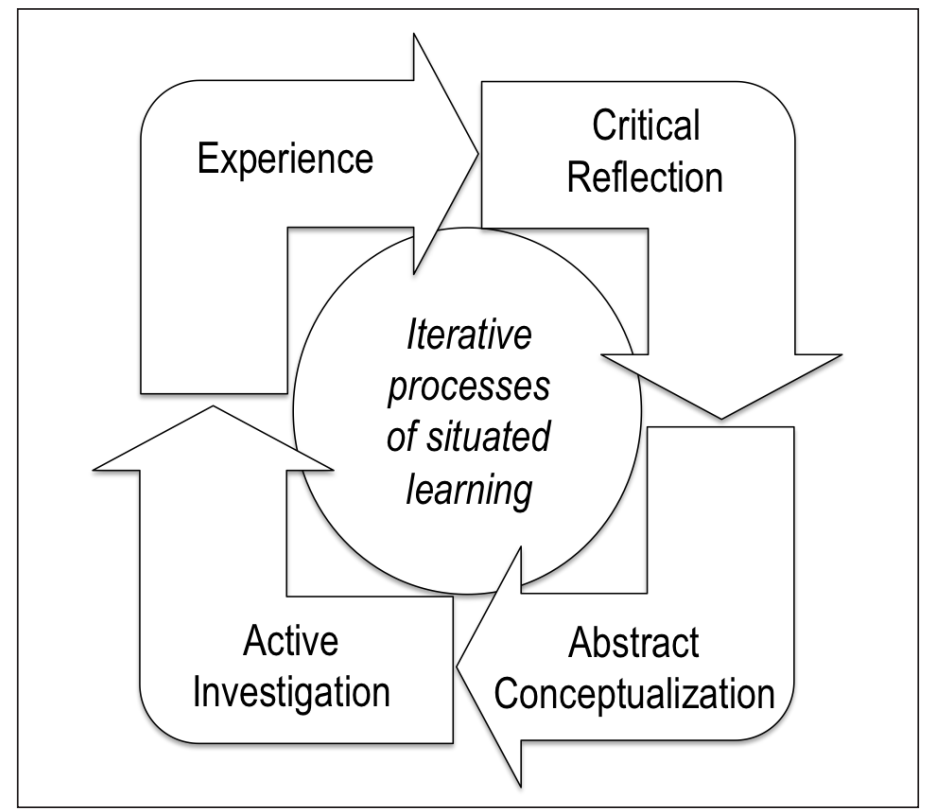

Fig. 2: Learning processes in situated cognition 
Situated cognition theory emphasizes that students do not learn effectively in a decontextualized setting, and implies that conceptual learning takes place best when students have the opportunity to learn from an authentic perspective. In terms of instructional implications, learning in a situated setting exploits the use of cognitive apprenticeship, learning communities, and assessment in situ (see Figure 3). This is sometimes phrased "lived practice," meaning that knowledge must be understood both in relation to social aspect as well as individual perspective (Driscoll, 2005).

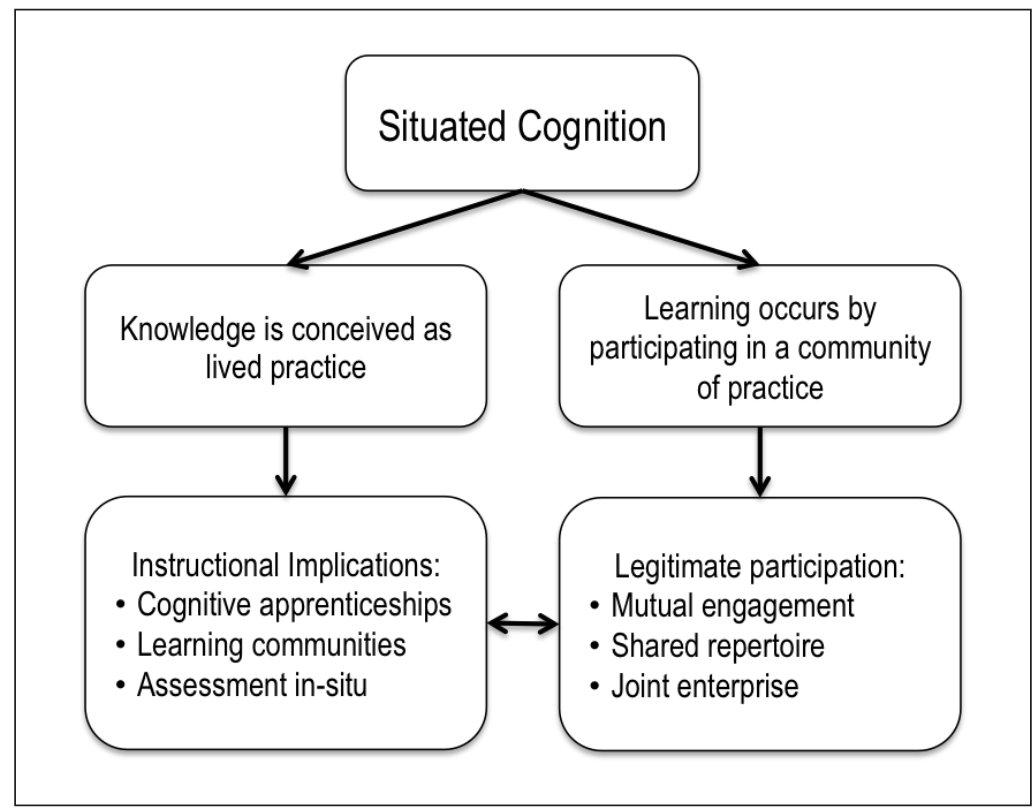

Fig. 3: Situated cognition framework

Students engaging in research projects need to enter the community of practice. The community of practice provides a setting for a process of social learning that occurs when individuals with a common interest in a problem collaborate over an extended period to share ideas, find solutions, and innovate (Wenger, 1998). Students participate in cognitive apprenticeships: "Cognitive apprenticeship methods try to enculturate students into authentic practices through activity and social interaction in a way similar to that evident - and evidently successful - in craft apprenticeship" (Brown et al., 1989, p. 37). Considering the instructional implications, and therefore applications, a situated cognitive model parallels well with an inquiry approach. 


\section{Inquiry Learning}

Inquiry, as described by the National Research Council (1996), encompasses "diverse ways in which scientists study the natural world and propose explanations based on the evidence derived from their work" (p. 23). Inquiry also refers to activities of students in which they acquire knowledge and understanding of scientific concepts, as well as problem-solving skills.

Shore and colleagues (2009) eloquently defined inquiry as "learning by questioning and investigation" (p. 141). They continued by stating that there are many approaches and questions that can be asked in this approach; the main requirement is that, "the goal of learning be simultaneously 'to do' and to 'learn about"' (p. 141). A pedagogical approach emphasizing inquiry learning is one that targets the acquisition of knowledge and process skills using research, emphasizes the promotion of open-mindedness while encouraging the balancing of alternative perspectives, and develops the skill, ability, and interest to work cooperatively with others (Joyce, Weil, \& Calhoun, 2008).

The use of inquiry has been shown to: improve content mastery and retention; result in imaginative, evidence-based explanations; increase positive perceptions of science; improve higher order thinking skills; and, consistently demonstrate gains in student learning (Furtak, Seidel, Iverson, \& Briggs, 2012; Lazonder, \& Harmsen, 2016; Shymansky, Hedges, \& Woodworth, 1990; Shore, Aulls, \& Delcourt, 2008; Smith, 1996). More refined research indicates that, while student autonomy is key to inquiry instruction, carefully facilitated guidance with focus on procedural, epistemic, and social features is necessary to increase critical thinking (Furtack et al., 2012; $\mathrm{Ku}, \mathrm{Ho}, \mathrm{Hau}, \&$ Lai, 201) and improve reflection (Linn, Eylon, Rafferty, \& Vitale, 2015). Within an inquiry-based learning environment, teachers can further encourage the development of student agency by making content relevant and engaging (Ferguson, Phillips, Rowley, \& Friedlander, 2015) through personalized student learning opportunities that ensure that the content and pacing of instruction match students' interests and skills. 


\section{Stories of Partnerships}

\section{Low Ropes Elements}

The program. As part of our instructional program, all 7th grade students take an adventure-based physical education class. Adventure-based learning uses physical group activities to facilitate leadership development, social responsibility, and teamwork. Students are presented with a challenge and must collaborate together to find a solution: these challenges require physical activity and collaboration. Two main tenets guide the program expectations: Challenge by Choice and the Full Value Contract. Challenge by Choice allows students to have the option to choose the level of participation based on personal comfort. Students are asked to respect the decisions of all team members. The intention is for students to feel supported in their choices and not peer-pressured. The Full Value Contract is an agreement that students make indicating that they all have the right to be valued in opinions, thoughts, and feelings. The Full Value Contract creates the class norms that all students sign and agree to follow.

The project. As part of our adventure programming, we wanted to create low ropes elements: challenges that take place close to the ground. These would be permanent structures on the school grounds. Serendipitously, we were approached by a local Fortune 500 technology company offering a "day of service" to schools. In the description, the company offered to come to schools to read to students, talk about careers, clean playgrounds, and other mundane, non-expertise-specific tasks. Knowing that this company employed a large number of engineers, I proposed an alternative: have the engineers come to the school to work with our students to build student-designed low ropes elements. The company agreed and we selected a fall day to conduct the build.

The team organizers who worked with us decided to apply for a community mini-grant through their company that would fund the materials necessary to build the elements. Our physical education teacher collaborated with the organizers to determine which elements to build. Ultimately, three were selected: wild woozy, alligator pits, and trolleys (see Figure 4). Students created design plans and worked with the organizers to create a materials list. 


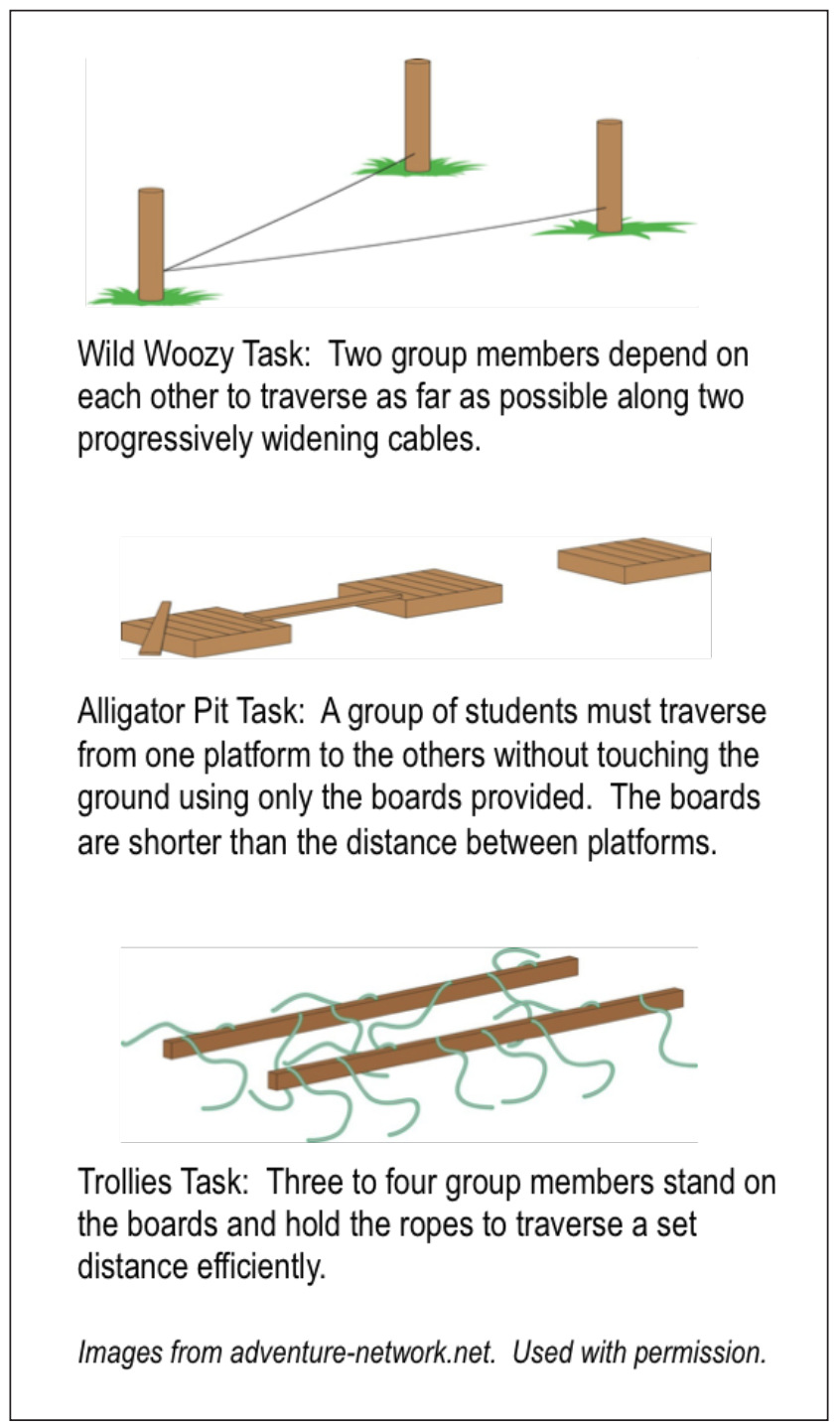

Fig. 4: Examples of low ropes element products created by students and engineers

The day of the build was picturesque: a beautiful crisp fall day with the autumnal colors of the deciduous trees as a backdrop. The team arrived complete with power tools, lumber, concrete, and extra goggles and gloves for students. After unloading, the project quickly began: lumber was cut, holes dug, materials shaped. Each time a student assumed a tool, an adult reviewed the safety procedures and would often intervene to offer suggestions for improvement. 
Perhaps the most revealing moment of the day came when one of the team organizers approached me to discuss the progress of the day. She said,

You know, we can never get our engineers to volunteer for anything, and yet here they are today working away. Generally it's our regular office and business people that volunteer. You've helped us find something that they were interested in and were excited about. Who wouldn't want to run their power tools outside on such a beautiful day?

We found that if we were to match talents with needs and have a scope that was not too extensive (e.g., a day of work), we could get volunteers to share their expertise in a meaningful, relevant way. We plan to continue to expand our low ropes elements in future years via this partnership.

\section{Invention Convention}

The program. The Invention Convention is a national program with state affiliates that allows students to develop, invent, innovate, and build entrepreneurship skills by creating a unique product (invention). The curriculum is standards-based and enables students to research, analyze, and effectively focus on and solve their authentic problems. We participate in a district-wide invention convention showcase and select our top $10 \%$ of projects to attend the statewide competition. The statewide competition hosts over 900 students annually. Because we conduct this program with our 100 incoming 6th grade STEM students, we prepare scaffolded activities to help them in the ideation and problem-finding phase (LaBanca \& Ritchie, 2011) as well as the problem-solving and presentation phases.

Take apart lab. An important part of invention is recognizing and understanding how things work (Gregory, 1970). We conduct a Take Apart Lab to explore this concept as well as give students experience working tactilely with tools. We invite our parents and guardians to provide us with their broken "stuff." That stuff might include small kitchen appliances, old computer printers, and other miscellaneous devices that no longer function. We get an overabundance of materials that are gladly and generously donated. This past year, our STEM theme coach found a full-size washing machine sitting on the side of the road awaiting pickup and snatched that for the lab. The purpose of the lab is for students to disassemble objects segment by segment, to gain an understanding of what each component does and how it interacts with other components. 
We schedule a four-hour window of lab time for the experience and invite parents and community members that have expertise to assist the students. We get an abundance of "dads," often with expertise in engineering and construction that participate. This is more frequently the underrepresented population in our school compared with our maternal figures. Those males often bring their friends to assist as well, so we extend our mentorship community with both male and female role models. We see students learning to use tools safely and efficiently. I've had the opportunity to observe technical conversations between adults and students that just could not happen with educators. We have a different skill set than other professionals. By recognizing our limitations and embracing others skills, we provide our students with a more robust learning experience.

Shark tank. After meaningful problem finding, iterations of development, and refinement of the product, our students prepare to present their results to the larger community audience. To prepare for this experience, we offer a Shark Tank experience. Roughly based on the American television show of the same name, our students stand in front of a panel of reviewers, present their work, and then are peppered with questions seeking explanation, rationale, justification for choices of the invention design.

Each panel takes place in the classroom with their teacher-advisor, an adult expert, and a 7th grade student. Our 7th grade students are chosen based on their success in the previous year as an invention convention participant. We ask the 7th grade students to write a statement indicating why they think they should be chosen as a panel member. A team of educators chose the students who participate. These slightly older role models take their job very seriously. They ask challenging questions and are coached to provide compassionate, positive feedback. By involving our older students, we are attempting to build the internal capacity of our organization to promote collaboration and support while increasing the overall quality of the student products.

Program improvement. We are still struggling with the overall quality of products for our invention convention program. Upon reflection and evaluation of the program, we are convinced that our students are capable of producing more consistent quality products across the grade level. We feel we have too much variance in quality. We want more products reflective of our top quartile. We are seeing too many products that are still too formative in nature, the prototypes lack functionality, or the presentation boards do not look professional. We plan to collaborate with our partners to identify additional strategies to improve the overall quality of this program. 


\section{Science Fair}

The program. Our Science Fair program has the goal of allowing 7 th and 8 th grade students to pursue research in biological, physical, medical, or engineering sciences. Students conduct an extended scientific experimental research or engineering design project. Students present the results of their research at our schoolwide fair, with the top 10 projects selected for participation in the state fair. The program is designed to provide students with the opportunity to participate in a significant research experience by selecting, developing, and conducting an independent project; and developing the skills of reporting and presenting research results to practicing scientists and engineers.

Similar to our Invention Convention program, we spend significant time and effort assisting students to problem find and ideate. We want students to identify a problem and consider its alternative views or definitions. Through this process, students set objectives, define purposes, decide what is interesting, and, ultimately, determining what to study. The progression involves an analysis of the ability to conduct the project. Do students have the necessary skills, access to experts, materials, equipment, and time to conduct a project that has value to an authentic audience? While coaching students, we purposely steer them away from pseudoscience projects (e.g., classical music impact on plant growth) as well as well-known questions with well-known outcomes (e.g., What paper towel is most absorbent? Does fertilizer help plants grow more efficiently?).

Scientific review committee. Because we promote high quality ideas, our students occasionally design projects that require a risk assessment to ensure that they comply with our State's guidelines. These guidelines are in alignment with the rules of the International Science and Engineering Fair (see: https://student.societyforscience.org/ intel-isef-forms). Risk assessment is associated with projects when students want to work with microorganisms, recombinant DNA, high voltage, lasers, human subjects, vertebrate animals, or toxic chemicals, to name a few. Although most projects do not require SRC review, for those that do, we encourage students to conduct a risk assessment with their mentor teacher and determine if resource access makes the project viable. If so, and the student wants to pursue, he or she must present the idea and risk assessment to the school's Scientific Review Committee (SRC). Note that the SRC serves as the school's Institutional Review Board/Ethics Board for projects with human subjects.

Our school's SRC, by design, consists of an administrator (me), a science teacher, the school nurse, and a scientist from the community. Our current scientist is a 
medical technologist who is a parent of one of our STEM students. When a student has a project that requires SRC review, we have them discuss the process with their mentor teacher. The student schedules an appointment with the office and comes to an SRC meeting with their mentor. The student makes a short presentation about what they intend to do, what safety procedures they are taking, and the resources they require. The mentor teacher is there only to coach as necessary: the ownership of the presentation belongs to the student. The SRC asks questions and provides advice. Sometimes the committee will discuss the experimental design and offer suggestions for improvement. These conversations tend to be very organic with a sharing of expertise from all participants. Upon conclusion, the SRC votes to approve the project and provides the student with a signed approval document.

School science fair presentations. Our culminating exposition of student work is our Science Fair Day. We invite scientists and engineers to participate as judges. Some of our judges are qualified parents, but the majority are community members. We seek those who are practicing scientists or engineers as evaluators. Teachers do not serve in this role: they assess the students' work separately. Their main role for this showcase is to assist and facilitate students so their presentations are high quality. They have rehearsed with students in class, perhaps helped them design singlesheet digital posters that are printed on our wide-format printer, and provided critical feedback on effective storytelling as a scientist.

The school's STEM Theme Coach assumes the responsibility to recruit the qualified scientists and engineers. Our initial list of judges was generated with assistance from our district STEM administrator, well-connected parents, partners at our local university's science departments, and contact with a former regional science fair organizer. It should be noted that many large companies will provide compensation time for employees who volunteer and many of our judges take advantage of this opportunity. We provide a continental breakfast for our judges and provide them with a ceramic coffee mug that is imprinted with the school's logo both for their coffee and as a thank-you gift. We also provide a short training session for our judges to review the judging criteria (see Figure 5) and to encourage them to provide a positive experience for the students. Although we are limited by the number of volunteers, we create judging teams that have to evaluate approximately 12 projects each. 


\begin{tabular}{|c|c|c|}
\hline PROJECT \# & PROJECT TITLE & STUDENT NAME \\
\hline $\begin{array}{l}\text { Scoring } \\
\text { Actual/ } \\
\text { Maximum }\end{array}$ & $\begin{array}{l}\text { Feedback (in the form of col } \\
\text { will be provided to students } \\
\text { _Strong (S) _ Average (A) }\end{array}$ & $\begin{array}{l}\text { mments, not point values) } \\
\text { _ Weak (W) }\end{array}$ \\
\hline $\begin{array}{l}\text { Research } \\
\text { Question } \\
\frac{/}{10 \text { points }}\end{array}$ & $\begin{array}{r}\text { RESEARCH QUESTION (10 } \\
\text { S_A_W Clear and focus } \\
- \text { S_A_W Identifies contri } \\
- \text { S_A_W Testable using s } \\
-\mathrm{S} \_ \text {A _W Engineering-Art } \\
\text { be solved. } \\
\text { S_A_W Engineering-Def } \\
\text { S_A_W Engineering-Exp }\end{array}$ & $\begin{array}{l}\text { POINTS MAXIMUM) } \\
\text { ed purpose of the project. } \\
\text { bution to field of study. } \\
\text { cientific methods. } \\
\text { iculation of practical need/ problem to } \\
\text { inition of criteria for success of solution. } \\
\text { lanation of constraints/assumptions. }\end{array}$ \\
\hline $\begin{array}{l}\text { Design and } \\
\text { Methodology } \\
\overline{15} \text { points }^{/}\end{array}$ & $\begin{array}{l}\text { DESIGN AND METHODOLC } \\
\text { S_A_W Well-designed } \\
\text { S_A_W Variables and cc } \\
\text { complete. } \\
- \text { S_A_W Testable using } \mathrm{C} \\
\text { S_A_W Engineering-Exp } \\
\text { S_A_W Engineering-Ide } \\
\text { S_A_W Engineering-De }\end{array}$ & $\begin{array}{l}\text { DGY (15 POINTS MAXIMUM) } \\
\text { ontrols defined, appropriate and } \\
\text { cientific methods. } \\
\text { loration of alternatives to problem. } \\
\text { ntification and description of a solution. } \\
\text { velopment of a prototype or model. }\end{array}$ \\
\hline $\begin{array}{l}\text { Execution: } \\
\text { Data } \\
\text { Collection } \\
\text { and Analysis } \\
\overline{20 \text { points }}\end{array}$ & 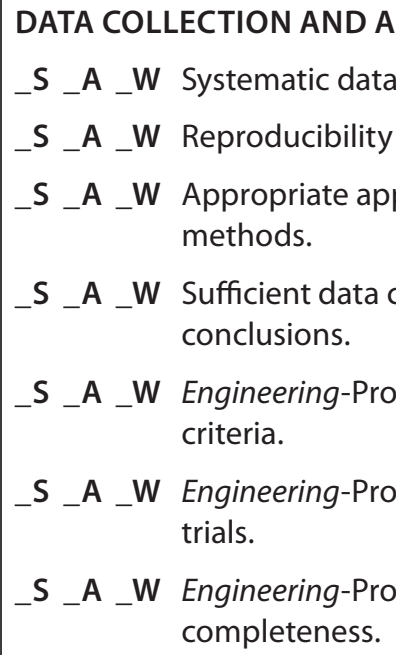 & $\begin{array}{l}\text { NALYSIS (15 POINTS MAXIMUM) } \\
\text { collection and analysis. } \\
\text { of results. } \\
\text { olication of analytical and statistical } \\
\text { ollected to support interpretation and } \\
\text { totype demonstrates intended design } \\
\text { totype tested in multiple conditions/ } \\
\text { totype demonstrates engineering skill }\end{array}$ \\
\hline
\end{tabular}




\begin{tabular}{|c|c|}
\hline$\overline{\text { Creativity }}_{20 \text { points }}^{/}$ & 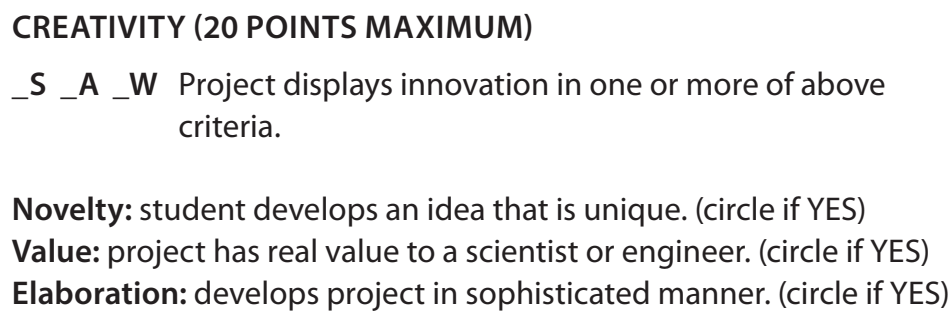 \\
\hline $\begin{array}{l}\text { Poster } \\
10 \text { points }\end{array}$ & 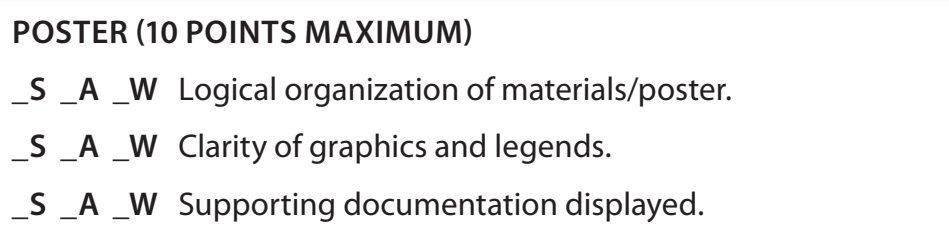 \\
\hline$\frac{\text { Interview }}{25 \text { points }}^{/}$ & 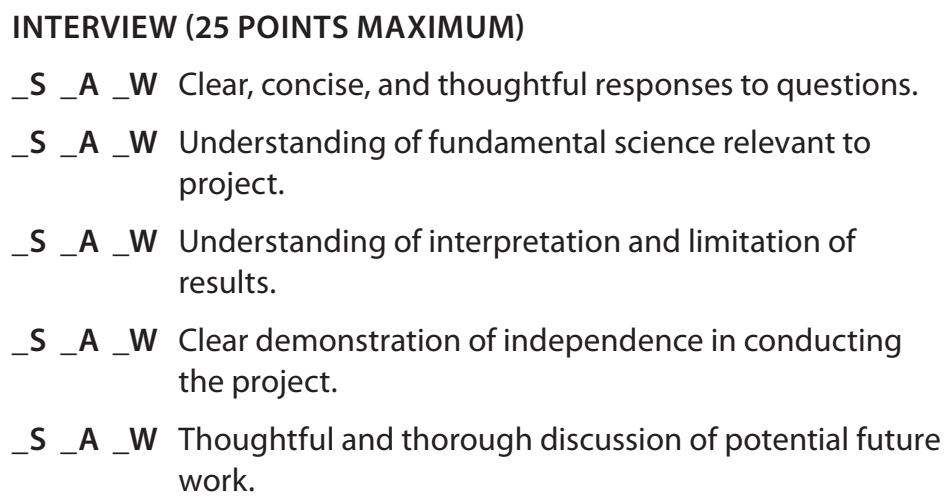 \\
\hline $\begin{array}{l}\text { TOTAL } \\
\text { POINTS } \\
\text { 100 points }\end{array}$ & COMMENTS: \\
\hline
\end{tabular}

Fig. 5: School science fair judging sheet 
We've designed the judging sheet to be in alignment with our school science fair rubric that teachers use and it is also aligned with the State's criteria. We've attempted to make it more user-friendly. The left side, which contains the scores, is detached for the score tabulations, and the right side, which contains space for feedback, is returned to the student. Our students dress to impress, and although initially express nervousness about the process, often comment that the conversations they have with the judges are the highlight of the process for them. They indicate to us that they are confidently able to speak about their projects and provide informed answers to judges' questions. Our judges concur: our most common comment, "I can't believe these are middle school students."

Program improvement. Our judging sheet is far from a perfect quantitative instrument and we recognize that our judges' conversations often far better elucidate the quality of projects. We have tried to use a more analytic style rubric at the state level, but that tends to bog down the judging process. We have found a more vague sheet where judges can make internal comparisons is far more efficient. We are still struggling with clear criteria for creativity and hope to refine that portion of the judging sheet in the future.

We are making high quality gains in consistency of projects. This year, of the 10 that were sent to the State Fair, eight were finalists - far higher than the state average of $20 \%$. We had several category winners including first, second, and fifth place in the state Fair's Urban School Challenge. Our school was the highest performing middle school in the State, garnering dozens of awards for these projects. Although we have more consistency, we still struggle with raising the quality of our lower quartile of projects. It is our continued work and we recognize that many of the answers lie in the problem-finding realm of the process.

\section{Quo Vadis?}

History day. With the national interest in STEM and STEM pipeline, opportunities for our STEM Academy students abound. With many options for extended inquiry learning, our students can share their work with an audience that finds value in their research. Because we value student-centered inquiry learning across both Academies, I wanted to ensure that our Global Studies program also was afforded these options. The History Day program is the STEM equivalent to the Science Fair. Similarly, there are regional competitions that proceed to state, and ultimately, national contests. 
History Day participants have different types of options for presentations: an exhibit, a documentary, a website, a presentation, or a paper. In order to showcase this work, we followed a similar procedure as our Science Fair process. We engaged our State History Day organization to help launch our program at the school and our 7th grade students leveraged many human resources that were available to them outside of the school. We conducted a school-wide History Day showcase where we invited scholars and those with appropriate expertise to come to the school and judge the projects and provide feedback. Parents were also invited to participate, view projects, and ask students questions. Similar to the Science Fair, our top students participated in the State History Day, with one team earning a slot to the national competition. We plan to expand the program to our 8th grade students this academic year so students can leverage their previous experience to produce even higher quality projects.

Scheduling. It should be noted that we dedicate courses to extended inquiry project-based learning. We do not feel that the caliber of work that we expect can be accomplished as an "add-on" to an academic course with an already packed curriculum. In order to create a meaningful student-centered environment, we find that students need time to problem find and problem solve, collaborate with others, and communicate their learning. Every student in our school has the time equivalent of an academic class for extended inquiry project-based learning.

We use an $A / B$, four-period block schedule so students have extended time with their teachers on a daily basis. Because we want inquiry instruction to permeate all instruction in all classes, longer class time is a necessity. In addition, approximately once every six weeks, we conduct a special-schedule "Project Day" where students have approximately four hours of time to work with their teachers on projects. Our Project Days often feature experts joining students in the learning process.

Reflection. We know that best practice indicates that students need opportunities to reflect on learning to best advantage. We developed a digital portfolio program to facilitate this process. At this point, our digital portfolios are more compliance-based than opportunities for students to grow and learn. We are dedicating time in the coming years for professional development around portfolio learning, portfolio audits, more opportunities for peer and adult feedback, and an annual portfolio showcase for students. 


\section{Conclusion}

The partnerships we develop with our community partners are based on harnessing their interests and expertise for a discrete timeframe. Although we have specific, curricular objectives, we dedicate our student-centered project-based learning to student choice-students determine the relevant areas they want to study within the constraints of their Academy themes. When students are given choices, it adds a level of flexibility to making partnerships. We recognize that our community partners are volunteering their time to make our school a better place. It is important that we show value to them by using their skills and talents.

\section{References}

Brown, J. S., Collins, A., \& Duguid, P. (1989). Situated cognition and the culture of learning. Educational Researcher, 18, 32-42.

Collins, A. (1988). Cognitive apprenticeship and instructional technology. Technical Report \#6899.

Driscoll, M. P. (2005). Psychology of learning for instruction. Boston: Allyn and Bacon.

Felicia, P. (Ed.). (2011). Handbook of research on improving learning and motivation through educational games: Multidisciplinary approaches. Hershey, PA: IGI Global.

Ferguson, R. F., Phillips, S. F., Rowley, J. F. S., \& Friedlander, J. W. (2015). The influence of teaching beyond standardized test scores: Engagement, mindsets, and agency. Cambridge, MA: The Achievement Gap Initiative at Harvard University. Retrieved from http://www.agi.harvard.edu/projects/ TeachingandAgency.pdf.

Furtak, E. M., Seidel, T., Iverson, H., \& Briggs, D. C. (2012). Experimental and quasiexperimental studies of inquiry-based science teaching: A meta-analysis. Review of Educational Research, 82(3), 300-329.

Gregory, R. L. (1970). The intelligent eye. London: Weidenfeld and Nicolson.

Joyce, B., Weil, M., \& Calhoun, E. (2008). Models of teaching. Boston: Pearson/Allyn and Bacon.
Kolb, D. (1984). Experiential learning: Experience as the source of learning and development. Englewood Cliffs, NJ: Prentice Hall.

Ku, K. Y. L., Ho, I. T., Hau, K-T., \& Lai, E. C. M. (2014). Integrating direct and inquiry-based instruction in the teaching of critical thinking: An intervention study. Instructional Science, 42, 251-269.

LaBanca, F., Lorentson, M., \& Oh, Y. J. (2016). EDUCATION CONNECTION's Center for 21st Century Skills: Development of an evidence-based technology-enhanced blended learning high school program. In C. Meyers \& W. C. Brant (Eds.) Implementation Fidelity in Education Research: Designer and Evaluator Considerations. New York: Routledge Press, Taylor \& Francis Group.

LaBanca, F., Oh, Y. J., Lorentson, M., Jia. Y., Sibuma, B., \& Snellback, M. (2014). BLENDED INSTRUCTION: Measuring the impact of a technology-enhanced student-centered learning environment on underserved student engagement, 21st century inquiry skill acquisition, and science achievement. Quincy, MA: Nellie Mae Education Foundation. Retrieved from http://www.nmefoundation. org/getattachment/Resources/StudentCentered-Learning/Blended-Instruction/ Blended-Learning-Report-April-2015. pdf?ext=.pdf 
LaBanca, F., \& Ritchie, K. C. (2011). The art of scientific ideas: Teaching and learning strategies that promote effective problem finding. The Science Teacher, 78(8), 48-51.

LaBanca, F., Worwood, M., LaSala, J., Schauss, S., \& Donn, J. (2013). Blended instruction: Exploring student-centered pedagogical strategies to promote a technology-enhanced learning environment. Litchfield, CT: EDUCATION CONNECTION. Retrieved from http://www.skills21.org/writable/images/ Blended_Learning_Paper-Skills21.pdf

Lazonder, A. W., \& Harmsen, R. (2016). Metaanalysis of inquiry-based learning: Effects of guidance. Review of Educational Research, 86(3), 681-718.

Linn, M. C., Eylon, B-S., Rafferty, A., \& Vitale, J. M. (2015). Designing instruction to improve lifelong inquiry learning. Eurasia Journal of Math, Science, and Technology Education, 11, (2), 217-225.

National Research Council. (1996). National science education standards. Washington, DC: National Academy Press.

Orey, M. (2010). Emerging perspectives on learning, teaching, and technology. Retrieved from http://epltt.coe.uga.edu/index.php? title=Main_Page
Shore, B. M., Aulls, M. W., \& Delcourt, M. A. B. (2008). Inquiry in education volume II: Overcoming barriers to successful implementation. Mahwah, NJ: Erlbaum.

Shore, B. M., Birlean, C., Walker, C. L., Ritchie, K. C., LaBanca, F., \& Aulls, M. W. (2009). Inquiry literacy: A proposal for a neologism. LEARNing Landscapes, 3, 139-156.

Shymansky, J. A., Hedges, L. V., \& Woodworth, G. (1990). A reassessment of effects of inquirybased science curriculum of the '60s on student performance. Journal of Research in Science Teaching, 27, 127-144.

Smith, D. (1996). A meta-analysis of student outcomes attributable to teaching science as inquiry as compared to traditional methodology. Unpublished doctoral dissertation, Temple University, Philadelphia.

Wenger, E. (1998). Communities of practice: Learning, meaning, and identity. New York: Cambridge University Press.

Wurdinger, D. D., \& Carlson, J. A. (2010). Teaching for experiential learning: Five approaches that work. Lanham, MD: Rowman \& Littlefield Education.

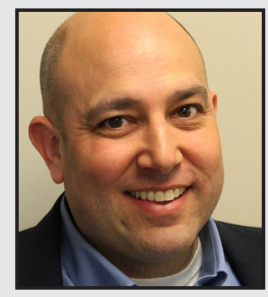

Frank LaBanca is a teacher, educational researcher, and change agent. Dr. LaBanca is the Founding Principal of Danbury, Connecticut's Westside Middle School Academy Magnet and the Executive Director of the National Center for Inquiry Learning. Previously, he was the Director of the Center for 21st Century Skills at EDUCATION CONNECTION, where he directed and managed the implementation of STEM programs in 50 high and middle schools. During his classroom career, Dr. LaBanca taught Biology and Applied Science Research at Stamford, Newtown, and Oxford High Schools in Connecticut. He is a Students at the Center Distinguished Fellow supported by Jobs for the Future and the Nellie Mae Education Foundation. 